\title{
GROUND-WATER AND STREAM-WATER INTERACTION IN THE OWL CREEK BASIN, WYOMING
}

By Kathy Muller Ogle

\section{U.S. GEOLOGICAL SURVEY}

Water-Resources Investigations Report 96-4253

Prepared in cooperation with the NORTHERN ARAPAHO TRIBE and the SHOSHONE TRIBE 


\section{U.S. DEPARTMENT OF THE INTERIOR BRUCE BABBITT, Secretary}

U.S. GEOLOGICAL SURVEY

GORDON P. EATON, Director

For additional information write to:

District Chief U.S. Geological Survey, WRD 2617 E. Lincolnway, Suite B Cheyenne, Wyoming 82001-5662
Copies of this report can be purchased from:

U.S. Geological Survey

Branch of Information Services

Box 25286, Denver Federal Center

Denver, Colorado 80225 


\section{CONTENTS}

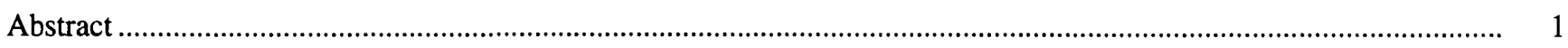

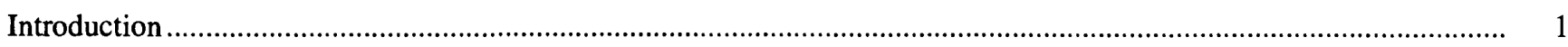

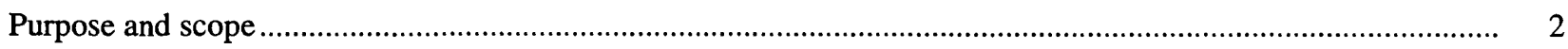

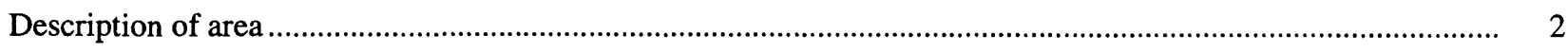

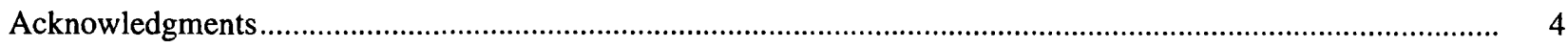

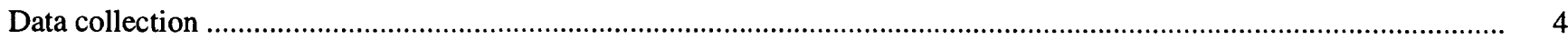

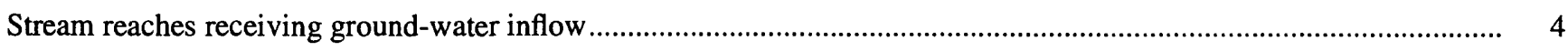

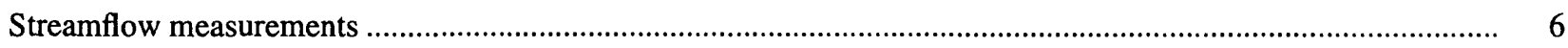

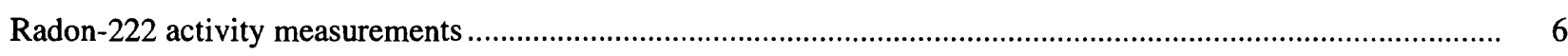

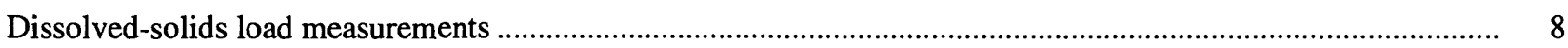

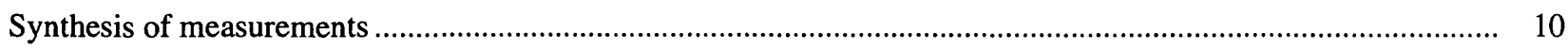

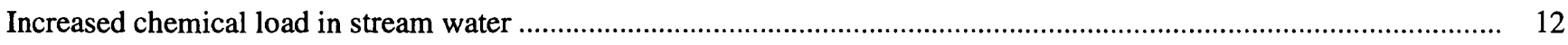

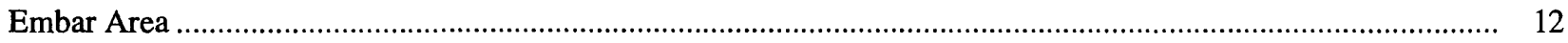

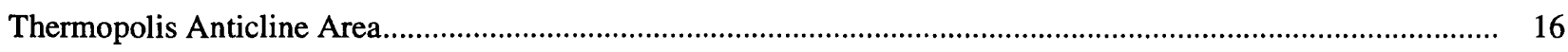

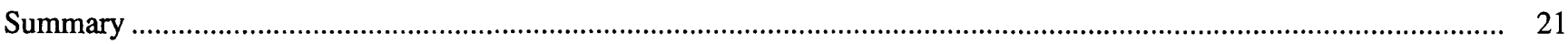

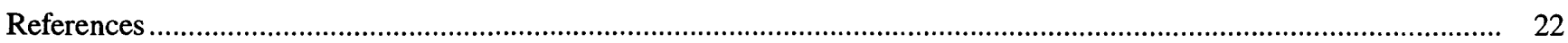

\section{FIGURES}

1-3. Maps showing:

1. Location of Owl Creek Basin

2. Location of water-sampling sites in Owl Creek Basin, Wyoming ......................................................... 3

3. Location of stream-sampling sites and stream reaches identified as receiving ground-water inflow using streamflow, radon-222 activity load, and increases in dissolved-solids load, Owl Creek Basin, Wyoming.

4. Graph showing dissolved-solids load for stream-water sampling sites, November 13-17, 1991,

Owl Creek Basin, Wyoming

5-7. Maps showing

5. Location of stream-water sampling sites, selected ground-water sampling sites, and Embar Area and Thermopolis Anticline Area, Owl Creek Basin, Wyoming

6. Generalized surficial geology, percent of drainage area, and percent of surficial geology in relation to stream-water sampling sites, North Fork Owl Creek, Owl Creek Basin, Wyoming

7. Generalized surficial geology, percent of drainage area, and percent of surficial geology in relation to stream-water sampling sites, South Fork Owl Creek and Red Creek, Owl Creek Basin,Wyoming ......

8-9. Graphs showing:

8. Altitude in relation to oxygen-18/oxygen-16, deuterium/hydrogen, and sulfur-34/sulfur-32 isotopes for stream-water sampling sites, Owl Creek Basin, Wyoming

9. Sulfate load in relation to unconsolidated deposits of Quaternary age, and to rocks of Cretaceous and Jurassic age at stream-water sampling sites, North Fork and South Fork Owl Creek and Red Creek, Owl Creek Basin, Wyoming.

10. Diagrammatic sketch of land surface and projected water level in the Thermopolis Anticline geothermal system, September 18, 1991, Owl Creek Basin, Wyoming

11. Graphs showing lithium to chloride ratio of water samples from stream- and ground-water sampling sites,

Owl Creek Basin, Wyoming 


\section{TABLES}

1. Geologic units used in calculation of areas of surficial geologic units, Owl Creek Basin, Wyoming

2. Streamflow measurements, error calculations, and identification of sampling points with significant increases in streamflow, Owl Creek Basin, Wyoming

3. Radon-222 activity, radon-222 activity load, analytical error, and identification of sampling points with

significant increases in radon-222 activity load, Owl Creek Basin, Wyoming ............................................
4. Dissolved-solids concentration, dissolved-solids load, and identification of sampling points with significant

4. Dissolved-solids concentration, dissolved-solids load, and identification
increases in dissolved-solids load, Owl Creek Basin, Wyoming

\section{CONVERSION FACTORS, VERTICAL DATUM, AND ABREVIATIONS}

\begin{tabular}{rll}
\hline Multiply & By & To obtain \\
\hline inch (in) & & \\
foot $(\mathrm{ft})$ & 25.4 & millimeter \\
mile $(\mathrm{mi})$ & 0.3048 & meter \\
square mile $\left(\mathrm{mi}^{2}\right)$ & 1.609 & kilometer \\
$\mathrm{acre}^{3}$ & 2.590 & square kilometer \\
cubic foot per second $\left(\mathrm{ft}^{3} / \mathrm{s}\right)$ & 0.4047 & hectare \\
& 0.02832 & cubic meter per second \\
\hline
\end{tabular}

\section{ABBREVIATIONS}

EPA

U.S. Environmental Protection Agency

MCL maximum contaminant level

SMCL secondary maximum contaminant level

USGS U.S. Geological Survey

$\mathrm{mg} / \mathrm{L}$ milligram per liter

$\mathrm{pCi} / \mathrm{L}$ picocurie per liter 


\title{
Ground-Water and Stream-Water Interaction in the Owl Creek Basin, Wyoming
}

\author{
By Kathy Muller Ogle
}

\section{ABSTRACT}

Understanding the interaction of groundwater and surface-water resources is vital to water management when water availability is limited. Inflow of ground water is the primary source of water during stream base flow and water chemistry of streams may be substantially affected by that inflow of ground water. This report presents results from a study to examine ground-water and surface-water interaction in the Owl Creek Basin, Wyoming completed by the U.S. Geological Survey in cooperation with the Northern Arapaho Tribe and the Shoshone Tribe.

During a low flow period from November 13-17, 1991, streamflow measurements and water-quality samples were collected at 16 selected sites along major streams and tributaries in the Owl Creek Basin. The data were used to identify stream reaches receiving ground-water inflow and to examine causes of changes in stream chemistry.

Three methods, streamflow measurements, radon-222 activity load, and dissolved-solids load, were used to identify stream reaches receiving ground-water inflow. Streamflow measurements identified three stream reaches receiving groundwater inflow. Analysis of radon-222 activity load identified five stream reaches receiving groundwater inflow. Dissolved-solids load identified six stream reaches receiving ground-water inflow. When these three methods were combined, stream reaches in two areas, the Embar Area and the Thermopolis Anticline Area, were identified as receiving ground-water inflow.

The Embar Area and the Thermopolis Anticline Area then were evaluated to determine the source of increased chemical load in stream water. Three potential sources were analyzed: tributary inflow, variation in surficial geology, and presence of anticlines. Two sources, tributary inflow and surficial geology, were related to changes in isotopic ratios and chemical load in the Embar Area. In two reaches in the Embar Area, isotopic ratios of oxygen-18/oxygen-16 $\left({ }^{18} \mathrm{O} /{ }^{16} \mathrm{O}\right)$, deuterium/ hydrogen $(D / H)$, and sulfur-34/sulfur-32 $\left({ }^{34} \mathrm{~S} /{ }^{32} \mathrm{~S}\right)$ indicated that tributary inflow affected streamwater chemistry. Increased chemical load of dissolved solids and dissolved sulfate in North Fork and South Fork Owl Creek appear related to the percentage of unconsolidated deposits of Quaternary age and deposits of Cretaceous and Jurassic age in the drainage area.

In the Thermopolis Anticline Area, changes in water chemistry in Owl Creek were not related to tributary inflow, surficial geology, or anticlines. The three tributaries flowing into Owl Creek in the Thermopolis Anticline Area did not substantially affect the isotopic ratios or contribute to the chemical load. Changes in the chemical load were not associated with changes in the surficial geology between the stream-water sampling sites. Water levels and chemical ratios indicate no groundwater inflow from the Thermopolis Anticline geothermal system to Owl Creek.

\section{INTRODUCTION}

Inflow of ground water is the primary source of water during stream base flow. During dry periods, all streamflow may be contributed by base flow (Todd, 1980). Literature related to base flow regression analysis was reviewed by Hall (1968). Hall noted that the ground-water component of stream base flow has been recognized since the 1840s and has been studied by a large number of French, United States, and British researchers.

Inflow of ground water may substantially affect the water chemistry of streams. Stream water during base flow periods generally contains larger concentrations of dissolved chemical constituents than during 
other flow periods. An inverse relation between streamflow and dissolved-solids concentration has been observed (Hem, 1989).

Understanding the interaction of ground-water and surface-water resources is vital to water management when water availability is limited. The Owl Creek Basin in Wyoming often experiences water shortages in late summer and fall. Changes in water quality in streams in the basin had been observed in a previous study (Ogle, 1992). These water-quality changes were sufficient to limit the suitability of the water for some purposes. Additional study was needed to identify whether those changes in stream-water quality were related to ground-water inflow. The work described in this report is part of a cooperative study between the U.S. Geological Survey and the Northern Arapaho Tribe and the Shoshone Tribe.

\section{Purpose And Scope}

This report describes the ground-water and stream-water interaction in the Owl Creek Basin, Wyoming (fig.1). This report has two objectives. The first objective is to identify stream reaches receiving ground-water inflow. Streamflow, radon-222 activity load, and dissolved-solids load were used to identify these stream reaches. The second objective is to determine the sources of increased chemical load in stream water. Changes in dissolved-solids load, isotopic ratios, and a chemical ratio in stream water were evaluated in relation to inflow from tributaries, changes in surficial geology, and presence of anticlines. The study was limited to an evaluation of the stream system in the middle and lower segments of the basin during low flow, November 13 - 17, 1991.

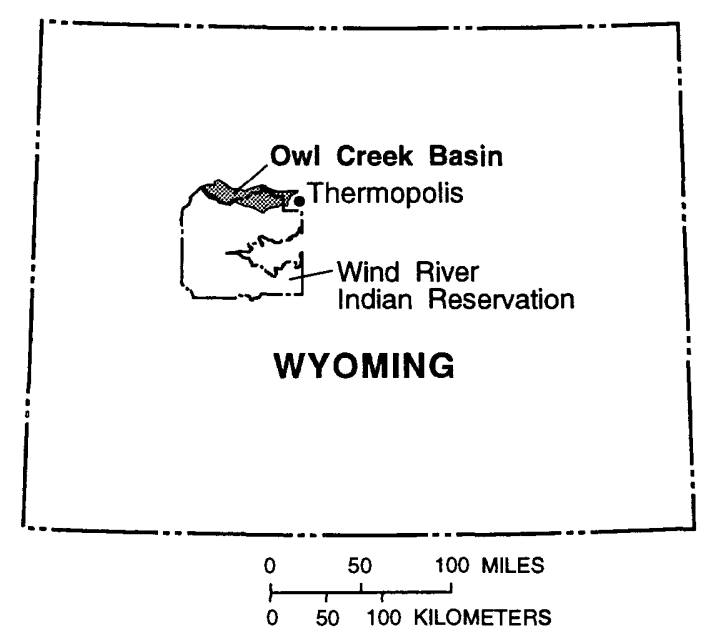

Figure 1. Location of Owl Creek Basin.
Streamflow was measured and water-quality samples were collected at 16 sites in the Owl Creek Basin to identify stream reaches that were gaining or losing water to the underlying ground-water system. Water-quality data were collected from six wells and five springs in or near the basin. The data collected from the wells and springs were used to characterize the water in the ground-water system. The streamwater data then were compared with the ground-water data to confirm the interaction between ground water and stream water that was indicated by the surfacewater analysis.

\section{Description Of Area}

Owl Creek Basin, located in north-central Wyoming (fig. 1), is topographically, geologically, and hydrologically diverse. The topographic relief of the area is dominated by the Owl Creek Mountains to the south, the Absaroka Range to the west, and the valley of Owl Creek and its major tributaries (fig. 2). The altitude ranges from about 4,300 feet above sea level near the mouth of the basin to about 12,518 feet above sea level in the headwaters. The geology of the basin is complex. Thirty surficial geologic units were preliminarily mapped by Love and others (1979). Twentynine synclines and anticlines, 33 faults, and 5 thrust faults were identified in Ogle (1992) at a 1:100,000 scale based on previous geologic mapping in the area. The climate, paralleling changes in altitude, varies from steppe in the lower parts of the basin to alpine tundra in the high mountainous areas (Martner, 1986). Owl Creek drains about a 509 square mile $\left(\mathrm{mi}^{2}\right)$ basin and flows generally from west to east.

Based on the chemical quality of stream water, the basin was subdivided (Ogle, 1992) into three distinct segments: upper, middle, and lower. The upper segment was characterized by an average dissolvedsolids concentration of $171 \mathrm{mg} / \mathrm{L}$ (milligrams per liter), the middle segment by an average of $566 \mathrm{mg} / \mathrm{L}$, and the lower segment by an average of $2,340 \mathrm{mg} / \mathrm{L}$. Stream water in each basin segment also had a different specific conductance to dissolved-solids concentration relation and a different water type based on major ion concentrations (Ogle, 1992). The average concentration of dissolved solids in the middle segment and the average concentrations of dissolved solids and sulfate in the lower segment exceeded the secondary maximum contaminant level of $500 \mathrm{mg} / \mathrm{L}$ for dissolved solids and $250 \mathrm{mg} / \mathrm{L}$ for sulfate established by U.S. Environmental Protection Agency Drinking-Water 


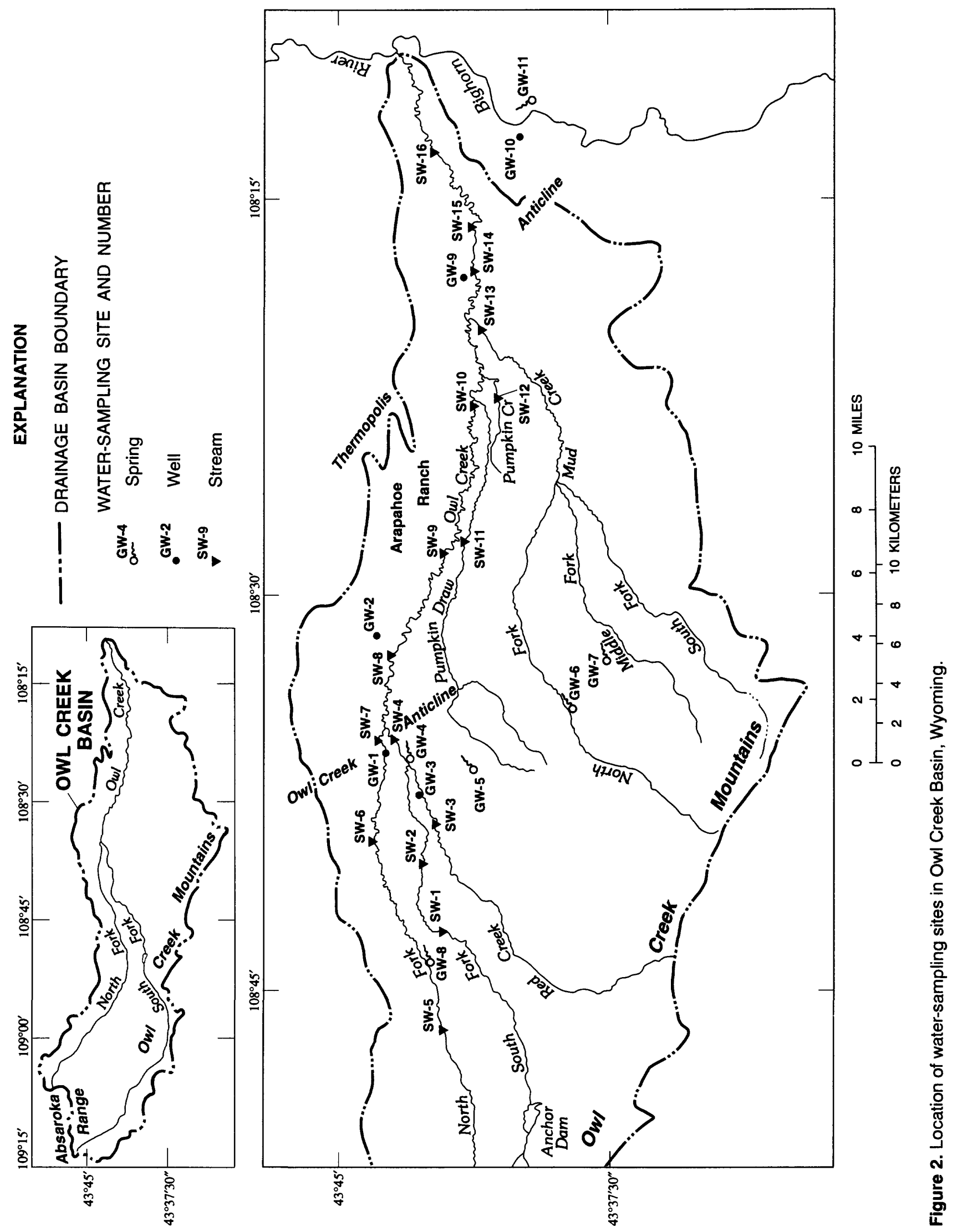


Regulations (U.S. Environmental Protection Agency, 1990). A secondary maximum contaminant level is a non-enforceable, aesthetically based, maximum concentration for contaminants in public drinking-water supplies.

\section{Acknowledgments}

The assistance and support of the Northern Arapaho Tribe, the Shoshone Tribe, and the U.S. Bureau of Indian Affairs are gratefully acknowledged. Assistance by Gary Holt, Wind River Environmental Quality Council, and Ed Shaffer, HD Ranch, in field data collection was appreciated. Access to sampling sites by residents and ranch managers was most helpful. Gary Collins and John Washakie gave generously of their time in directing the project in its initial stages.

\section{DATA COLLECTION}

Stream-water and ground-water sampling sites were selected in the approximate lower two-thirds of Owl Creek Basin where stream-water chemical changes were observed in a previous study (Ogle, 1992). An initial field screening of 40 stream-water sampling sites was made in October 1991. Streamflow was estimated, and $\mathrm{pH}$ and specific conductance were measured at each site during the field screening. Sixteen of the 40 stream sites were selected (fig. 2) for more detailed sampling. The selected sites are located along major streams and at all tributaries between sampling points on the major streams.

The 16 stream-water sampling sites were selected at sections of the streams between riffles and pools that were assumed, based on field conditions, to be well mixed. During November 13 - 17, 1991, instantaneous streamflow was measured, and water samples were collected for analysis of $\mathrm{pH}$, temperature, specific conductance, radon-222 activity, selected ions, trace elements, and isotopes. Stream sites were sampled during low flow conditions; streamflow ranged from about 0.02 to 18 cubic feet per second $\left(\mathrm{ft}^{3} / \mathrm{s}\right)$. Streamflow was measured using methods described by Rantz and others (1982).

Ground-water samples were collected for analysis at six wells and five springs between September 1991 and March 1992 (fig. 2). Prior to sampling, water was pumped from wells until the $\mathrm{pH}$, temperature, and specific conductance of the water stabilized. Water samples were collected at the point of discharge for wells and springs to minimize contact of the water with the atmosphere and were analyzed for the same constituents as the stream-water samples.

Water samples for chemical analysis were collected and analyzed using procedures described in Fishman and Friedman (1989). Radon-222 activities were measured onsite using alpha-scintillation counting cells and a Tennelec model AC/DC-DRC-MK 10 dual radon counting system ${ }^{1}$ according to the methodology and calculations described by the U.S. Environmental Protection Agency (1980). Details of the radon-222 sampling procedure are described in Ogle and Lee (1994). Water-quality analyses for major ions and trace elements were completed by the U.S. Geological Survey (USGS) Laboratory in Arvada, Colorado. Analysis of water samples included alkalinity and dissolved concentrations of calcium, magnesium, sodium, potassium, chloride, sulfate, fluoride, silica, arsenic, boron, and lithium. Dissolved-solids concentrations were calculated from major-ion concentrations. Tritium and oxygen-18/oxygen- $16\left({ }^{18} \mathrm{O} /{ }^{16} \mathrm{O}\right)$, and deuterium/hydrogen $(\mathrm{D} / \mathrm{H})$ isotopic ratios were determined by the USGS Research Laboratory in Reston, Virginia. The sulfur-34/sulfur-32 $\left({ }^{34} \mathrm{~S} /{ }^{32} \mathrm{~S}\right)$ isotopic ratios were determined by the USGS Research Laboratory in Lakewood, Colorado.

The area of each surficial geologic unit in the drainage area above and between each stream-water sampling site was calculated using a geologic map (1:100,000 scale) from Ogle (1992) (table 1). Areas were compiled for geologic units based on available mapping in the area (Love and Christiansen, 1985; Love and others, 1979; and Ogle, 1992) and similarity of formations.

The location of anticlines was determined using the same geologic map $(1: 100,000$ scale $)$ from Ogle (1992). For this study, anticline locations were plotted where the crestal plane of the anticline was inferred to intersect the stream.

\section{STREAM REACHES RECEIVING GROUND-WATER INFLOW}

The interaction of ground water with streams theoretically can be characterized by four models. The first is a no-interaction model, where water is not exchanged between the stream and the ground water.

\footnotetext{
${ }^{1}$ Use of the brand names in this report is for identification purposes only and does not constitute endorsement by the U.S. Geological Survey.
} 
Table 1. Geologic units used in calculation of areas of surficial geologic units, Owl Creek Basin, Wyoming

\begin{tabular}{|c|c|}
\hline Geologic unit & System/Series \\
\hline $\begin{array}{l}\text { Unconsolidated deposits } \\
\text { (This unit includes bottomland, alluvial, terrace, } \\
\text { colluvial, pediment, landslide, and talus deposits) }\end{array}$ & Quaternary \\
\hline $\begin{array}{l}\text { Absaroka Volcanic Supergroup } \\
\text { (This unit includes the Wiggins, Tepee Trail, and Aycross } \\
\text { Formations) }\end{array}$ & Tertiary \\
\hline $\begin{array}{l}\text { Cretaceous to Jurassic deposits } \\
\text { (This unit includes the Mesaverde Formation, Cody Shale, } \\
\text { Frontier Formation, Mowry Shale, Muddy } \\
\text { Sandstone, Thermopolis Shale, Cloverly Formation, } \\
\text { Morrison, Sundance, and Gypsum Spring Formations, } \\
\text { and Nugget Sandstone [Jurassic (?) and Upper } \\
\text { Triassic (?)]) }\end{array}$ & Cretaceous through the Jurassic \\
\hline \multicolumn{2}{|l|}{ Pre-Jurassic Deposits } \\
\hline $\begin{array}{l}\text { Chugwater and Dinwoody Formations, and Phosphoria } \\
\text { Formation }^{1} \text { and related rocks }\end{array}$ & Triassic to Permian \\
\hline Tensleep Sandstone and Amsden Formation & $\begin{array}{l}\text { Pennsylvanian to Upper } \\
\text { Mississippian }\end{array}$ \\
\hline Madison Limestone and Darby Formation & $\begin{array}{l}\text { Upper and Lower Mississippian and } \\
\text { Upper Devonian }\end{array}$ \\
\hline $\begin{array}{l}\text { Upper Ordovician to Middle Cambrian rocks } \\
\text { (Comprises Bighorn Dolomite, Gallatin Limestone, Gros } \\
\text { Ventre Formation, and Flathead Sandstone) }\end{array}$ & $\begin{array}{l}\text { Upper Ordovician to Middle } \\
\text { Cambrian }\end{array}$ \\
\hline Igneous and metamorphic rocks & Precambrian \\
\hline
\end{tabular}

${ }^{1}$ In Wyoming, the Phosphoria Formation is synonymous with the Park City Formation (Lane, 1973, p. 4)

The second is a losing-stream model, where water from the stream discharges to the ground water. The third is a gaining-stream model, where ground water discharges to the stream. The fourth is a combination gaining- and losing-stream model, where both conditions occur within the reach. Only the gaining-stream model and the combination gaining- and losing-stream model are of interest in this study because they identify stream reaches receiving ground-water inflow.

Adjacent upstream and downstream streamflow measurements, radon-222 activity loads, and dissolvedsolids loads were compared to identify stream reaches receiving ground-water inflow. The error associated with streamflow measurements, radon-222 activity measurements, and dissolved-solids loads was considered in the determination that an observed change was a measurable change. Only measurable changes, that is changes greater than the associated measurement error, were used to identify stream reaches receiving groundwater inflow. Mixing calculations were used where tributary inflow occurred, in order to evaluate change at the next downstream sampling point.

A number of assumptions are inherent in this analysis of the interaction of ground water and stream water. Streamflow was assumed to approximate steady-state conditions except for ground-water and stream-water interactions. Evapotranspiration was assumed to be negligible during the stream-water sampling period. These two assumptions were supported by the following site conditions: freezing temperatures each night, negligible precipitation or runoff, dormant period for vegetation, and sufficient time for major effects of irrigation to dissipate. Also, radon-222 activity in a sample collected from the center of a well- 
mixed section of the stream was assumed to represent the radon-222 activity of the stream water at that sampling site. This assumption is supported by the work completed by Lee and Hollyday (1991) who successfully used this sampling technique to determine ground-water inflow to streams. Ground-water inflow to the stream was assumed to have a higher concentration of radon-222 activity than streamflow. Lee and Hollyday (1987) reported that ground water can contain radon-222 activities ranging from two to four orders of magnitude higher than radon-222 activities in surface water. Ogle and Lee (1994) found samples in this study to have a median of 373 picocuries per liter $(\mathrm{pCi} / \mathrm{L})$ of radon-222 activity for the ground-water samples and a median of $8 \mathrm{pCi} / \mathrm{L}$ of radon-222 activity for the stream-water samples. Identification of stream reaches with increased dissolved-solids load assumed no major dissolution or precipitation of minerals in the stream bed. A limitation of the study was that none of the methods will detect ground-water inflow that is less than the measurement error associated with the method.

\section{Streamflow Measurements}

A common method to detect ground-water inflow to a stream reach is the comparison of upstream and downstream streamflow measurements. Streamflow measurements have accuracy limitations depending on equipment and streamflow conditions. Rantz and others (1982) summarized some of the errors associated with single discharge measurements and concluded that if the standard recommended methods were followed, two-thirds of the measured discharges would have errors less than 2.2 percent. Specific site conditions may increase that error. Detection of groundwater inflow may be difficult from streamflow measurements if the quantity of ground-water inflow is small or if measurement errors associated with site conditions are large.

Analysis of streamflow measurements identified three stream reaches as receiving ground-water inflow (fig. 3). The difference in flow at adjacent downstream and upstream sites for each of the 16 stream-water sampling sites was compared. An estimated error of 8 percent, plus or minus, was assigned to each streamflow measurement, in accordance with standard USGS methodology. Ground-water inflow was identified when the downstream measurement minus the associated 8-percent error was larger than the upstream measurement plus the associated 8-percent error. If tributary inflow occurred between the two sites, that inflow, along with its associated measurement error, was considered in evaluating an increase in streamflows. The stream reaches identified as receiving ground-water inflow and the associated changes in streamflow are listed in table 2.

\section{Radon-222 Activity Measurements}

Increased or stable radon-222 activities have been successfully used in other studies to identify areas of ground-water inflow (Lee and Hollyday, 1987 and Rogers, 1958). Radon-222 is a product of the uranium-238 decay series (Wanty and Schoen, 1991). Radon-222 is a noble gas, with a half-life of 3.82 days (Whittaker and others, 1987), and does not react with other constituents in water; however, the gas does dissipate into the atmosphere. Dissipation of the gas results in a decreased radon-222 activity in stream water downstream from the source. The rate of decrease of radon-222 activity is dependent on factors affecting the aeration of the water which were not quantified in this study.

Analysis of radon-222 activity load identified five stream reaches as receiving ground-water inflow (fig. 3). Stream reaches identified as receiving groundwater inflow and the associated changes in radon- 222 activity and load are listed in table 3 . Radon-222 activity load was calculated to allow this comparison. Ground-water inflow to a stream reach was identified by comparing the radon-222 activity load at adjacent upstream and downstream sites. An increase in radon222 activity load in a stream reach indicated groundwater inflow as its source. Likewise, if the radon-222 activity load at the downstream site was equal to the radon-222 activity load at the upstream site, then additional radon-222 input from ground-water inflow was indicated to replace the radon-222 gas that dissipated over the reach. Mixing calculations were used where tributary inflow occurred to determine any change at the downstream sampling point. No conclusions can be drawn from the data if the radon-222 activity load was less at the downstream site than at the upstream site because the rate of dissipation of radon- 222 is unknown. Measurement and counting errors were associated with individual radon-222 activity measurements (Ogle and Lee, 1994). The measurement errors were considered in the analysis, and only stream reaches where the increase in radon-222 activity load was greater than the errors associated with the measurements were identified as receiving groundwater inflow. Ground-water samples had a median radon-222 activity of $373 \mathrm{pCi} / \mathrm{L}$, confirming there was sufficient radon-222 activity in the ground water to provide additional radon- 222 activity to the surface water. 


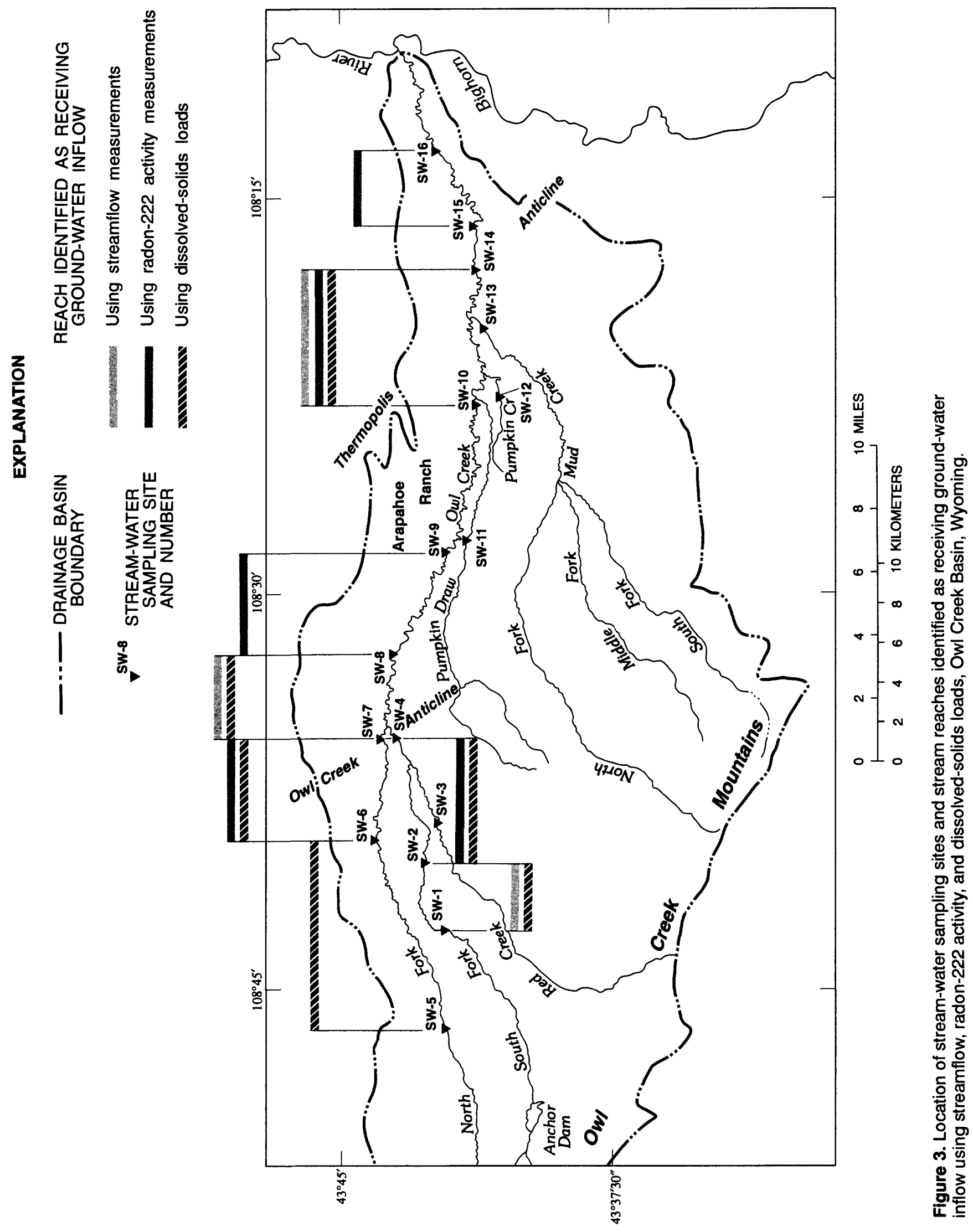


Table 2. Streamflow measurements, error calculations, and identification of sampling points with significant increases in streamflow, Owl Creek Basin, Wyoming

[NA, not applicable; \%, percent]

\begin{tabular}{llcccc}
\hline \multirow{2}{*}{$\begin{array}{c}\text { Site number } \\
\text { (fig. 2) }\end{array}$} & \multicolumn{1}{c}{ Site name } & \multicolumn{3}{c}{ Flow, in cubic feet per second } & Significant \\
\cline { 3 - 5 } & & Minus 8\% & Measured & Plus 8\% & increase \\
\hline SW-1 & South Fork Owl Creek at bridge & 0.69 & 0.75 & 0.81 & NA \\
SW-2 & South Fork Owl Creek at Embar & 1.9 & 2.1 & 2.3 & Yes \\
SW-3 & Red Creek & 4.2 & 4.6 & 5.0 & NA \\
Adjusted for mixing SW-2 and SW-3 & 6.1 & 6.7 & 7.3 & NA \\
SW-4 & South Fork Owl Creek at trailer & 6.3 & 6.8 & 7.3 & No \\
SW-5 & North Fork Owl Creek at bridge & 5.0 & 5.4 & 5.8 & NA \\
SW-6 & North Fork Owl Creek at Section 31 & 4.8 & 5.2 & 5.6 & No \\
SW-7 & North Fork Owl Creek at knob & 5.3 & 5.8 & 6.3 & No \\
Adjusted for mixing of SW-4 and SW-7 & 12 & 13 & 14 & NA \\
SW-8 & Owl Creek at Arapahoe Ranch & 15 & 16 & 17 & Yes \\
SW-9 & Owl Creek at Middleton School & 12 & 13 & 14 & No \\
SW-10 & Owl Creek at steel bridge & 3.7 & 4.0 & 4.3 & No \\
SW-11 & Pumpkin Draw & .19 & .21 & .23 & NA \\
SW-12 & Pumpkin Creek & .02 & .02 & .02 & NA \\
SW-13 & Mud Creek & .06 & .06 & .06 & NA \\
Adjusted for mixing of SW-10, SW-11, SW-12, and SW-13 & 4.0 & 4.3 & 4.6 & NA \\
SW-14 & Owl Creek at Highway 120 & 14 & 15 & 16 & Yes \\
SW-15 & Owl Creek at sand points & 16 & 17 & 18 & No \\
SW-16 & Owl Creek at Pumping Station & 17 & 18 & 19 & No \\
\hline
\end{tabular}

${ }^{1}$ Calculated by reducing the measured flow by 8 percent. Resulting number was then rounded.

${ }^{2}$ Calculated by increasing the measured flow by 8 percent. Resulting number was then rounded.

\section{Dissolved-Solids Load Measurements}

Ground-water inflow to streams may affect the chemical quality of stream water because ground water commonly has a larger concentration of dissolved chemicals than stream water. The chemical effect of ground-water inflow on stream-water quality is most significant during base flow periods. Chemical effects produced by ground-water inflow were noted by researchers from the 1940s through the 1960s. By the late 1960s, the chemical effects of ground-water inflow had been used to estimate quantities of ground-water inflow (Hall, 1968).

Analysis of dissolved-solids load identified six stream reaches as receiving ground-water inflow (fig. 3). Stream reaches identified as receiving groundwater inflow and the associated changes in dissolvedsolids load are listed in table 4. Dissolved-solids load was calculated for each stream-water sampling site. This calculation consisted of multiplying the streamflow by the concentration of the dissolved solids; the result was the dissolved-solids load transported by the stream at a specific site. The dissolved-solids load at each stream-water sampling site was compared to the load at the next downstream sampling site. Percentage increases in dissolved-solids greater than 18 percent were used to identify stream reaches receiving groundwater inflow. When mixing of two streams or tributary inflow occurred, the dissolved-solids load was calculated for each stream or tributary. The dissolved-solids loads were summed and compared to the dissolvedsolids load calculated at the next downstream sampling site. The general increase of dissolved-solids load in stream-water samples collected in Owl Creek Basin is illustrated in figure 4. 
Table 3. Radon-222 activity, radon-222 activity load, analytical error, and identification of sampling points with significant increases in radon-222 activity load, Owl Creek Basin, Wyoming

[NA, not applicable]

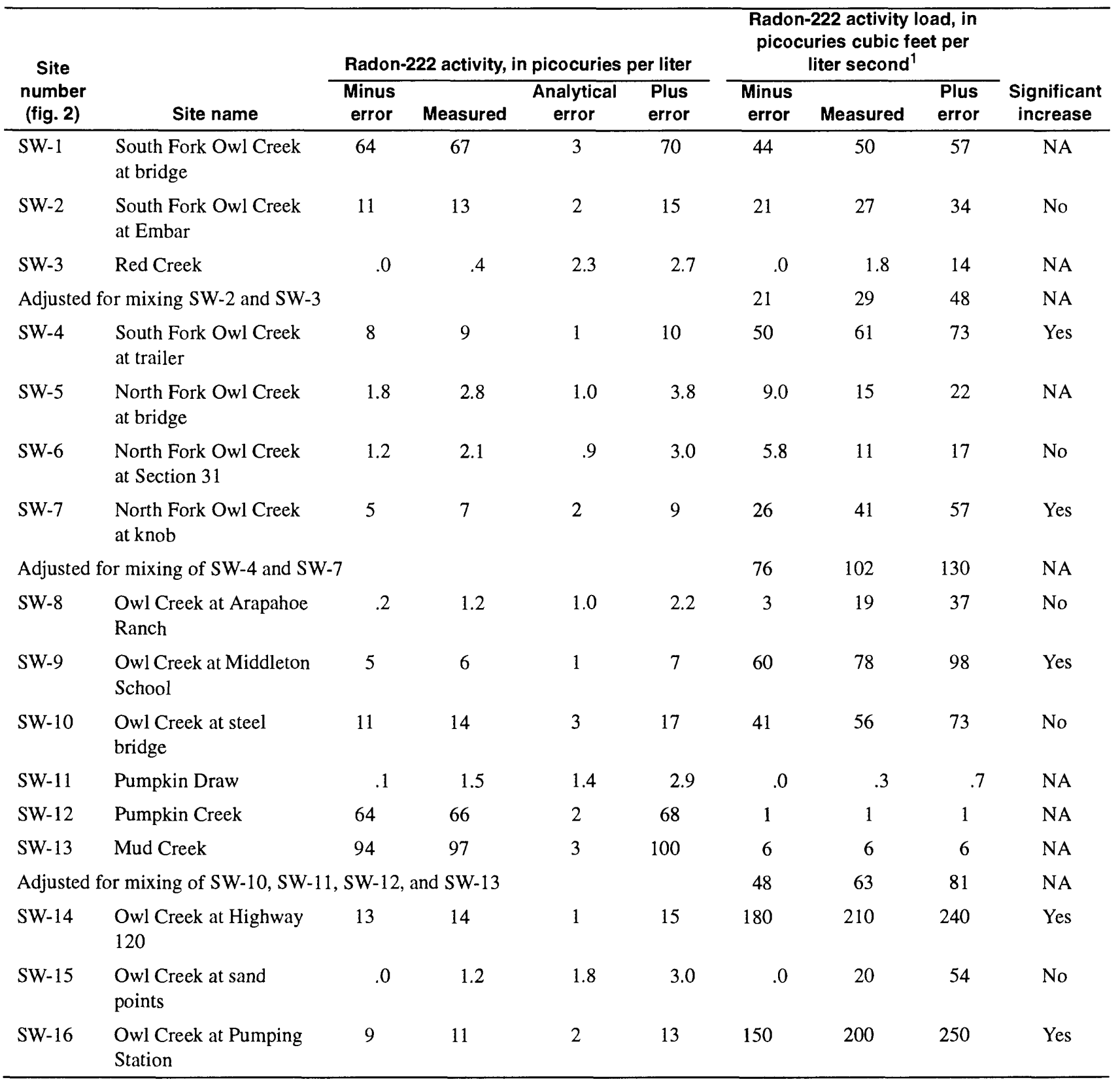

\footnotetext{
${ }^{1}$ Calculated by multiplying the radon-222 activity by the streamflow measurement. Resulting number was then rounded.
} 
Table 4. Dissolved-solids concentration, dissolved-solids load, and identification of sampling points with significant increases in dissolved-solids load, Owl Creek Basin, Wyoming

[NA, not applicable]

\begin{tabular}{|c|c|c|c|c|c|}
\hline $\begin{array}{c}\text { Site } \\
\text { number } \\
\text { (fig. 2) }\end{array}$ & Site name & $\begin{array}{l}\text { Dissolved } \\
\text { solids, in } \\
\text { milligrams per } \\
\text { liter }\end{array}$ & $\begin{array}{l}\text { Dissolved- } \\
\text { solids load, in } \\
\text { milligrams } \\
\text { cubic feet per } \\
\text { liter second }\end{array}$ & $\begin{array}{l}\text { Percent } \\
\text { change in } \\
\text { dissolved- } \\
\text { solids load }\end{array}$ & $\begin{array}{l}\text { Significant } \\
\text { increase }\end{array}$ \\
\hline SW-1 & South Fork Owl Creek at bridge & 1,560 & 1,170 & NA & NA \\
\hline SW-2 & South Fork Owl Creek at Embar & 1,210 & 2,540 & +117 & Yes \\
\hline SW-3 & Red Creek & 254 & 1,170 & NA & NA \\
\hline \multicolumn{3}{|c|}{ Adjusted for mixing SW-2 and SW-3 } & 3,710 & NA & NA \\
\hline SW-4 & South Fork Owl Creek at trailer & 683 & 4,640 & +25 & Yes \\
\hline SW-5 & North Fork Owl Creek at bridge & 241 & 1,300 & NA & NA \\
\hline SW-6 & $\begin{array}{l}\text { North Fork Owl Creek at Section } \\
31\end{array}$ & 336 & 1,750 & +34 & Yes \\
\hline SW-7 & North Fork Owl Creek at knob & 499 & 2,890 & +65 & Yes \\
\hline \multicolumn{3}{|c|}{ Adjusted for mixing of SW-4 and SW-7 } & 7,530 & NA & NA \\
\hline SW-8 & Owl Creek at Arapahoe Ranch & 653 & 10,450 & +39 & Yes \\
\hline SW-9 & Owl Creek at Middleton School & 843 & 10,960 & +5 & No \\
\hline SW-10 & Owl Creek at steel bridge & 1,140 & 4,560 & -58 & No \\
\hline SW-11 & Pumpkin Draw & 2,690 & 565 & NA & NA \\
\hline SW-12 & Pumpkin Creek & 3,070 & 61 & NA & NA \\
\hline SW-13 & Mud Creek & 1,230 & 74 & NA & NA \\
\hline \multicolumn{3}{|c|}{ Adjusted for mixing of SW-10, SW-11, SW-12, and SW-13 } & 5,260 & NA & NA \\
\hline SW-14 & Owl Creek at Highway 120 & 2,220 & 33,300 & +533 & Yes \\
\hline SW-15 & Owl Creek at sand points & 1,960 & 33,320 & $<-1$ & No \\
\hline SW-16 & Owl Creek at Pumping Station & 1,950 & 35,100 & +5 & No \\
\hline
\end{tabular}

${ }^{1}$ Calculated by multiplying the dissolved-solids concentration by the streamflow measurement. Resulting number was then rounded.

Dissolved-solids chemical load was assumed to have an error of 18 percent, plus or minus. The 18 percent error was based on two effects: an 8 percent error associated with the streamflow measurement and a 10 percent error associated with the dissolved solids concentrations. The 8 percent error, plus or minus, associated with the streamflow measurement, was a conservative estimate based on standard USGS methodology. The 10 percent error, plus or minus, associated with the dissolved-solids concentration was based on two pairs of duplicate samples, collected at streamwater sampling sites SW-4 and SW-16. In the duplicate samples, variation between concentrations of the constituents used in the chemical load analysis ranged from about 1 to 8 percent; thus, the 10 percent was a conservative estimate.

\section{Synthesis of Measurements}

A total of eight stream reaches were identified as receiving ground-water inflow by synthesizing or combining the results of the three measurements used to determine ground-water inflow: streamflow, radon-222 activity load, and dissolved-solids load. One stream reach (SW-10 to SW-14) was identified by all three measurements. Two stream reaches (SW-1 to SW-2 and SW-4, SW-7, to SW-8) were identified by streamflow measurements and dissolved-solids load. Two stream reaches (SW-2 to SW-4 and SW-6 to SW-7) were identified by radon-222 activity and dissolvedsolids load. Two stream reaches were identified only by radon- 222 activity load, and one stream reach was identified only by dissolved-solids load. 


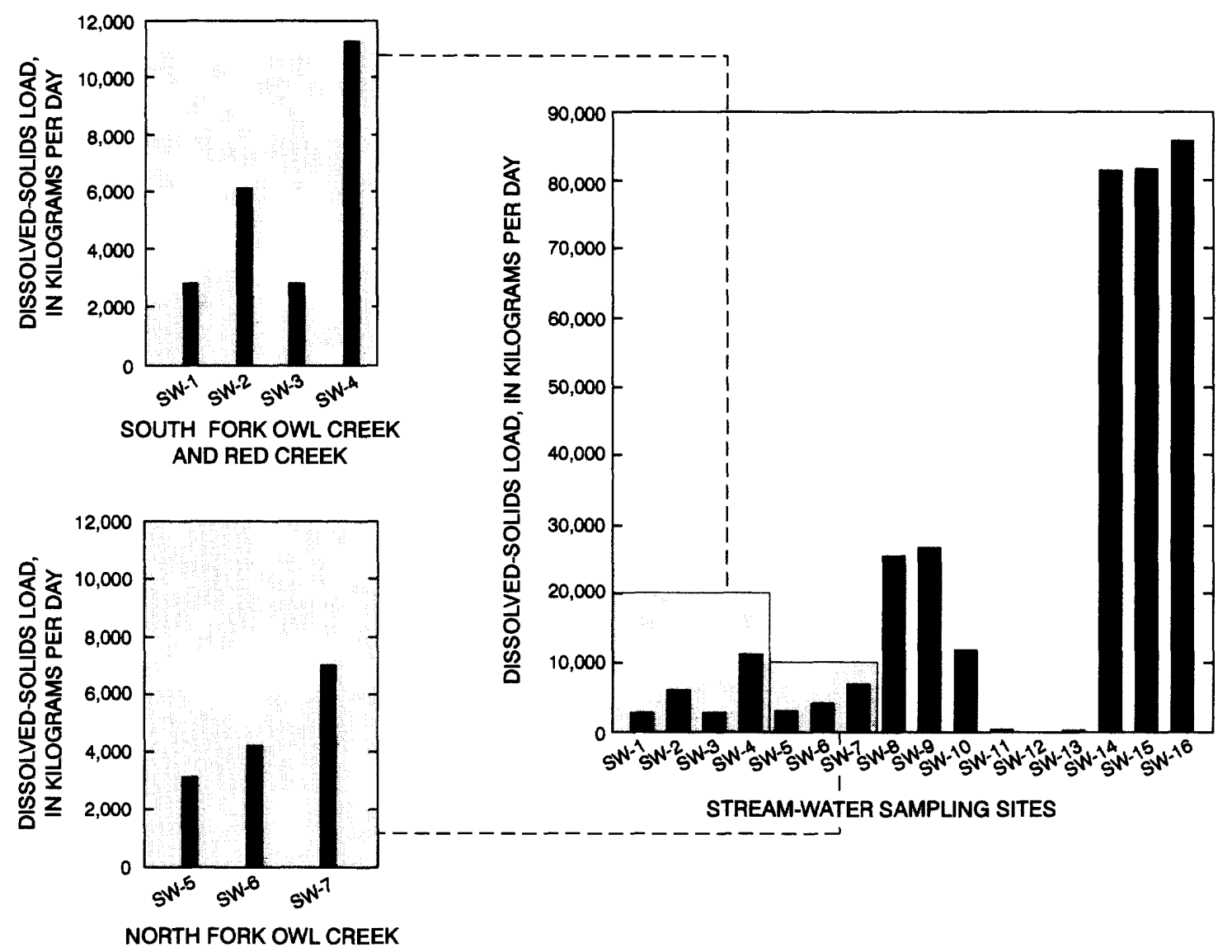

Flgure 4. Dissolved-solids loads for stream-water sampling sites, November 13-17, 1991, Owl Creek Basin, Wyoming.

The results of the three measurements were evaluated for stream reaches where the results differed. Two stream reaches (SW-8 to SW-9 and SW-15 to SW-16) were identified only by radon-222 activity. Streamflow in reach SW-15 to SW-16 increased, but the increase was less than the estimated measurement error. Reach SW-8 to SW-9 had a decrease in streamflow (table 2 ) but an increase in radon-222 activity (table 3). A possible explanation for the differing results of the two measurements might be that the reach is a combination gaining and losing stream reach in which there was a net loss. The inflow from ground water, in part of the reach, would contribute to higher radon-222 activity. This combination condition could have resulted in decreased streamflow and an increase in radon-222 activity.

Ground-water inflow to one stream reach (SW-5 to SW-6) was identified only by increased dissolvedsolids load. On the basis of field observations, the reach had sections of turbulent flow that might have increased the dissipation of radon-222 activity, resulting in lower activities. The difference in streamflow measurements between SW-5 and SW-6 was small.

Based on a synthesis of reaches of streams independently identified as receiving ground-water inflow using streamflow, radon-222 activity load, and dissolved-solids load, the Embar Area and the Thermopolis Anticline Area (fig. 5) were identified as areas of ground-water inflow to streams. All reaches identified by at least one type of measurement as receiving ground-water inflow were included in the two areas except the two reaches identified only by radon- 222 measurements (SW-8 to SW-9 and SW-15 to SW-16). The two reaches identified only by radon-222 were not considered because one reach had a substantial decrease in streamflow and both reaches had changes in dissolved-solids load less than the percentage error of estimate. 
Two stream reaches were identified as not receiving ground-water inflow. Reach SW-9 to SW-10 was losing streamflow to ground water. Streamflow and dissolved-solids load measurements indicated a gaining reach for SW-14 to SW-15, but the increases were less than the estimated measurement error.

\section{INCREASED CHEMICAL LOAD IN STREAM WATER}

Stream reaches shown to receive ground-water inflow by individual measurements were synthesized to identify the Embar Area and the Thermopolis Anticline Area where streams received ground-water inflow. Potential sources of increased chemical load were examined in those two areas. Changes in chemical load, isotopic ratios, and chemical ratios in stream water were evaluated in relation to tributary inflow, surficial geology, and presence of anticlines in the Embar Area and the Thermopolis Anticline Area. Mixing of two waters of different chemical quality generally results in a water of intermediate chemical quality downstream (Fritz, 1981). Isotopic ratios often may be used as signatures to quantify the effect of tributary inflow if the tributary has different isotopic ratios than the main stream. Linear mixing calculations were used to examine the effect of tributary inflow.

Ground water discharging to streams from surficial geologic units was postulated as a possible source of increased chemical load in the streams of Owl Creek Basin. Some sediments, occurring naturally or through weathering processes, have soluble minerals that may be dissolved by ground water. Thus, the chemical quality of ground water commonly reflects the geology of the rocks through which the water flows. If the ground water then discharges into streams, the water chemistry of the streams may be affected. Kalkhoff (1993) determined a relation between some water-quality properties and constituents in Roberts Creek in Clayton County, Iowa, and the underlying geology. Drever (1982) reported that stream-water chemistry generally reflects the chemical composition of the near-surface ground water. See and others (1992) determined that median selenium discharge correlated with total area, area of the Cody Shale of Cretaceous age, or alluvium of Quaternary age derived from the Cody Shale. For Owl Creek Basin, where increases in chemical loading appeared to be directly related to the percentage of the drainage area underlain by a geologic unit located between sampling sites, the increase might be caused by ground water associated with the geologic unit.

Ground water flowing from deeper bedrock aquifers through secondary permeability, associated with anticlines, and discharging into Owl Creek was postulated as a possible source of increased chemical loads. In Owl Creek Basin, several large anticlines have been mapped (Spencer, 1986; Heasler, 1985; and Hinckley and others, 1982) and identified as having increased secondary permeability due to fracturing. Hinckley and others (1982) indicated that secondary permeability allows interconnection between several bedrock aquifers in the Thermopolis Anticline and determined that ground water in the Thermopolis Anticline geothermal system likely originates in the Madison Limestone of Mississippian age, flows upward through fractures or faults, and discharges at land surface in the Thermopolis Hot Springs area. Water collected at stream sampling sites located above and below where the streams cross the anticlines in the Embar Area and the Thermopolis Anticline Area was analyzed to determine if chemical load, isotopic ratios, and chemical ratios were related to the presence of anticlines. Dissolved solids and sulfate load, differences in the isotopic ratios of ${ }^{18} \mathrm{O} /{ }^{16} \mathrm{O}, \mathrm{D} / \mathrm{H}$, and ${ }^{34} \mathrm{~S} /{ }^{32} \mathrm{~S}$, and lithium to chloride chemical ratios were used to examine if changes in stream water might be related to deeper ground-water flow at anticlines.

\section{Embar Area}

The Embar Area (fig. 5) includes the downstream reaches of North Fork and South Fork Owl Creek, part of the downstream reach of Red Creek, and a small part of the upstream reach of Owl Creek. North Fork Owl Creek, with a drainage area of about $100 \mathrm{mi}^{2}$, is related to the stream-water sampling sites in the following manner: 75 percent is above stream-water sampling site SW-5, 17 percent is between SW-5 and SW-6, and 8 percent is between SW-6 and SW-7 (fig. 6). South Fork Owl Creek, with a drainage area of about $126 \mathrm{mi}^{2}$, is related to the stream-water sampling sites in the following manner: 89 percent is above SW-1, 2 percent is between SW-1 and SW-2, and 9 percent is between SW-2 and SW-4 (fig. 7). Red Creek, with a drainage area of about $42 \mathrm{mi}^{2}$, flows into South Fork Owl Creek between sampling sites SW-2 and SW-4 (figs. 5 and 7). 


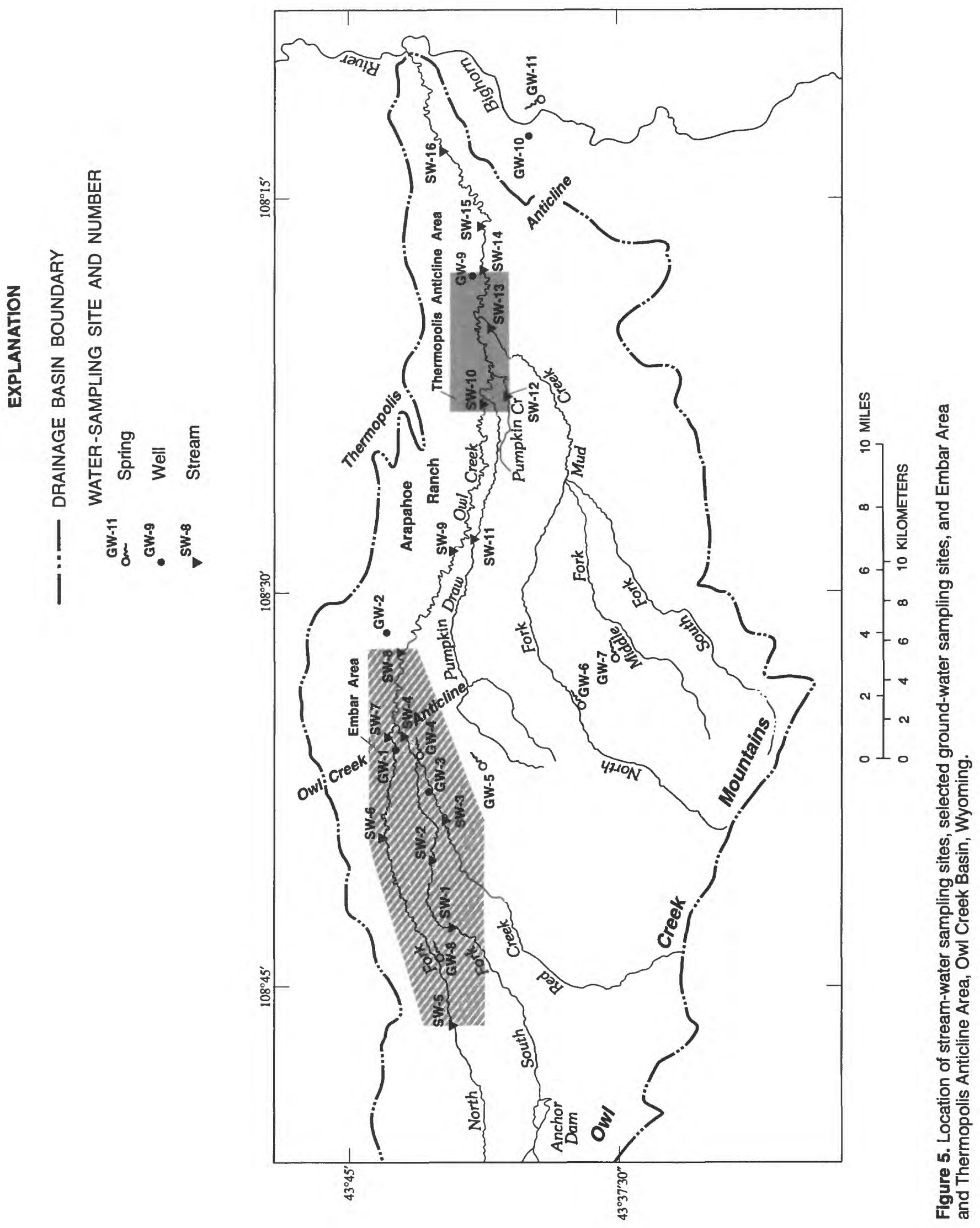




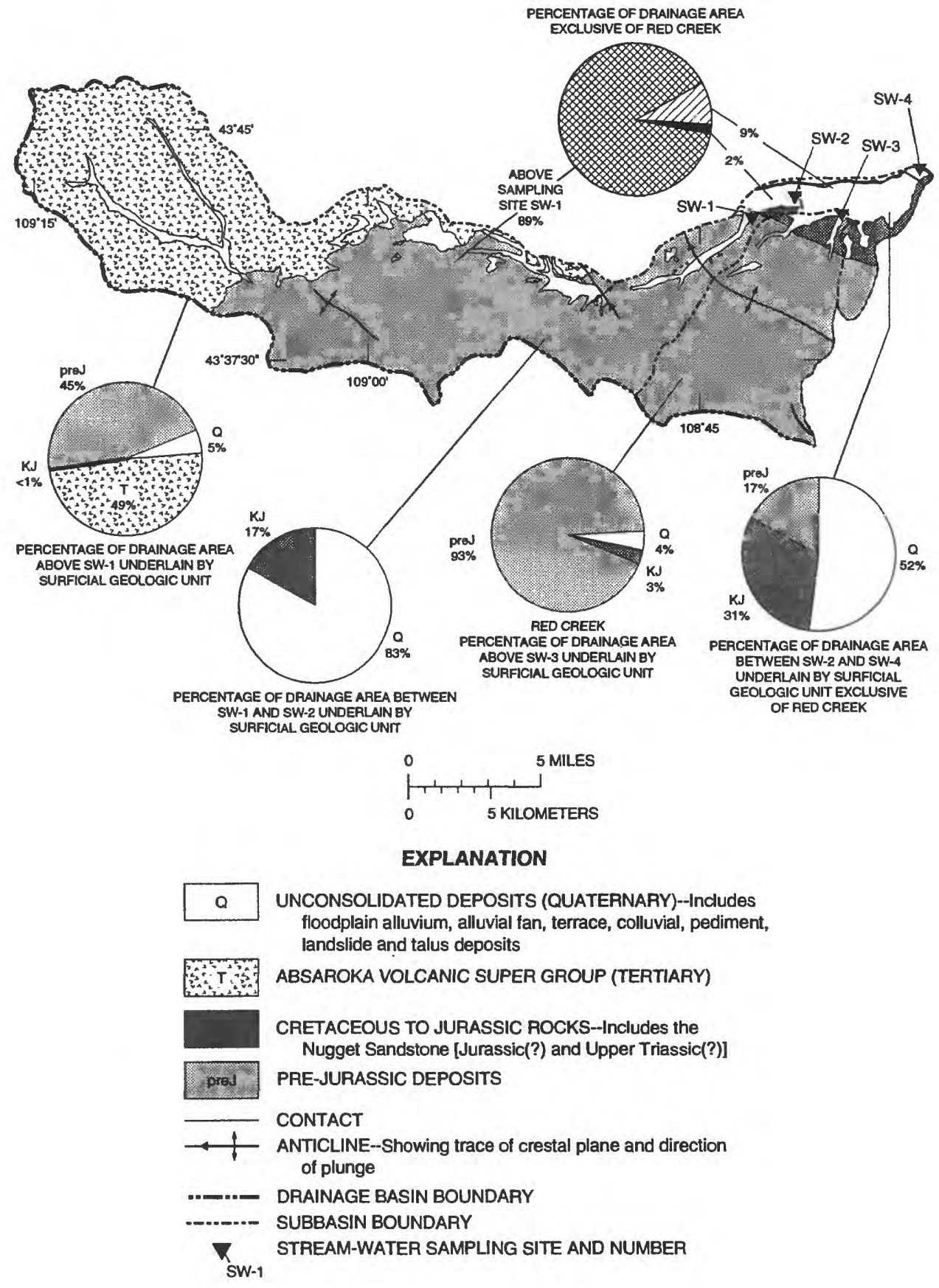

Figure 6. Generalized surficial geology, percentage of drainage area, and percentage of drainage area underlain by surficial geologic units in relation to stream-water sampling sites, North Fork Owl Creek, Wyoming. 


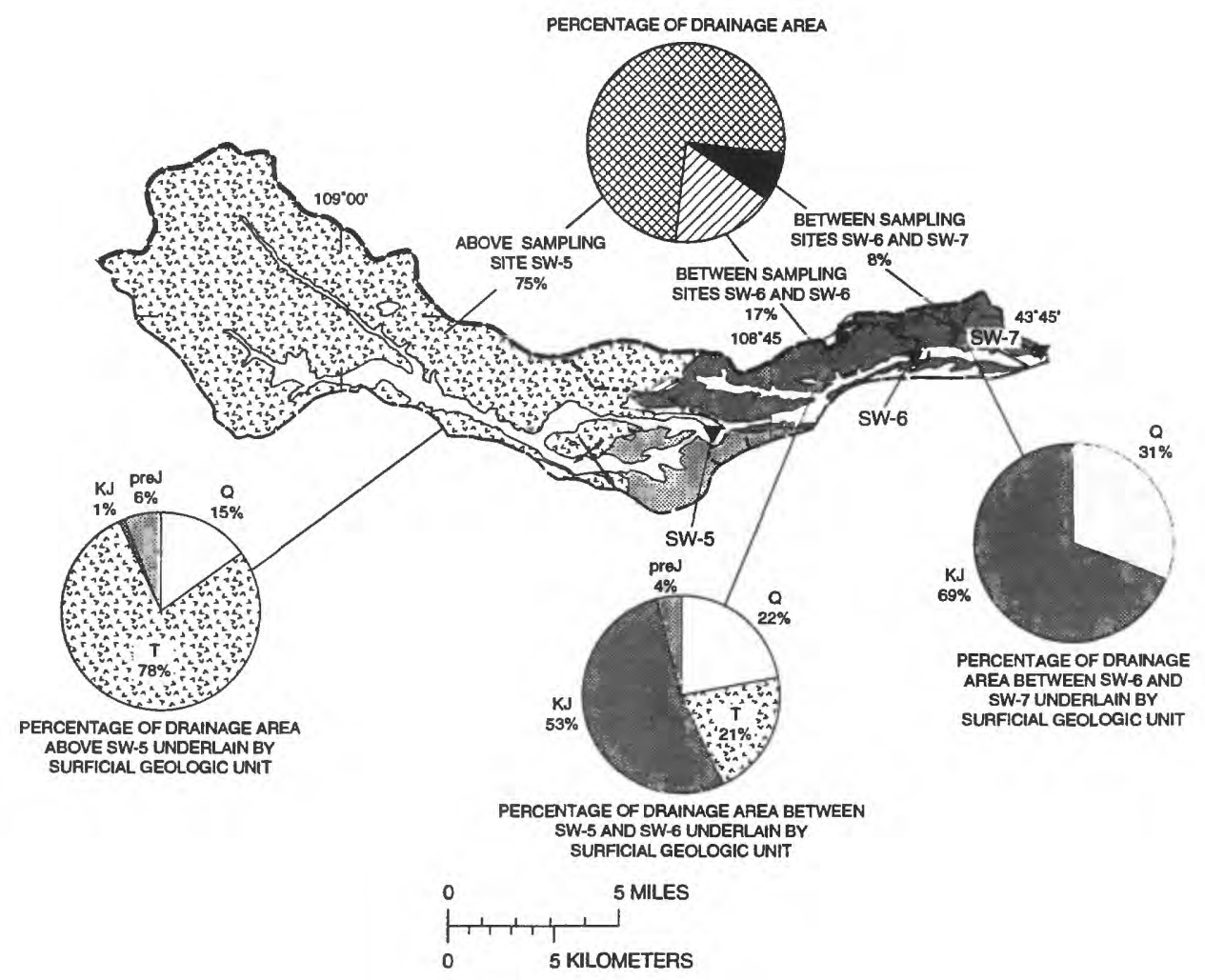

EXPLANATION

Q UNCONSOLIDATED DEPOSITS (QUATERNARY)--Includes floodplain alluvium, alluvial fan, terrace, colluvial, pediment, landslide and talus deposits

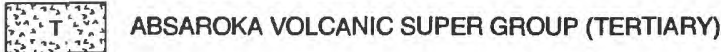

CRETACEOUS TO JURASSIC ROCKS--Includes the
Nugget Sandstone [Jurassic(?) and Upper Triassic(?)]
PRE-JURASSIC DEPOSITS
CONTACT
OFe
ONTICLINE--Showing trace of crestal plane and direction
Of plunge

Figure 7. Generalized surficial geology, percentage of drainage area, and percentage of drainage area underlain by surficial geologic units in relation to stream-water sampling sites, South Fork Owl Creek and Red Creek drainage basins, Wyoming. 
Surficial geology changes from the headwater area to the Embar Area. The Absaroka Volcanic Supergroup of Tertiary age is the most areally extensive geologic unit in the headwater area of the Owl Creek Basin, underlying about 63 percent of the North Fork Owl Creek drainage area (fig. 6) and about 44 percent of the South Fork Owl Creek drainage area (fig. 7). Cretaceous-Jurassic deposits crop out in the middle and lower parts of the North Fork and South Fork Owl Creek drainage basins. Unconsolidated deposits of Quaternary age are located primarily along principal drainages throughout the basin.

Tributary inflow affected the stream-water chemistry at two points in the Embar Area. In downstream order, the first point of tributary inflow was at the junction of Red Creek and South Fork Owl Creek (fig. 5). The effect of this mixing is observable by examining ${ }^{18} \mathrm{O} /{ }^{16} \mathrm{O}, \mathrm{D} / \mathrm{H}$, and ${ }^{34} \mathrm{~S} /{ }^{32} \mathrm{~S}$ isotopic ratios (fig. 8). The ${ }^{18} \mathrm{O} /{ }^{16} \mathrm{O}$ and $\mathrm{D} / \mathrm{H}$ isotopic signatures of the water in Red Creek (SW-3) were lighter (more negative) than other stream-water samples in the basin. When water from Red Creek mixed with water in South Fork Owl Creek, a water with an intermediate isotopic signature was produced (SW-4) (fig. 8). The second point of tributary inflow was at the confluence of North Fork and South Fork Owl Creek. Water chemistry at the first stream-water sampling site on the main stem of Owl Creek (SW-8) appeared to be primarily affected by mixing of water from the two tributaries. The ${ }^{18} \mathrm{O} /{ }^{16} \mathrm{O}$ and $\mathrm{D} / \mathrm{H}$ isotopically heavier water in North Fork Owl Creek (SW-7) mixed with the isotopically lighter water in South Fork Owl Creek (SW-4), producing a water with an intermediate isotopic signature (fig. 8). A secondary effect, however, occurred that was not accounted for by the mixing. The sum of the sulfate load from North Fork and South Fork Owl Creek accounted for only 79 percent of the sulfate load at a sampling site (SW-8) downstream of the confluence.

Increased chemical load of sulfate in North Fork and South Fork Owl Creek appear to be directly related to the percentage of unconsolidated Quaternary deposits and of Cretaceous-Jurassic deposits in the drainage area (table 1 and fig. 9). The effects of these two geologic units could not be separated, which was not unexpected because significant portions of the unconsolidated sediments are derived from the adjacent and underlying Cretaceous-Jurassic deposits.

The changes in chemical load, isotopic ratios, and chemical ratios did not indicate any ground-water inflow that could be associated with the Owl Creek Anticline located in the Embar Area (fig. 5). Two factors-tributary inflow and surficial geology-appeared to be related to changes in stream-water chemistry in the Embar Area.

\section{Thermopolis Anticline Area}

Ground-water inflow and changes in stream-water chemical quality were determined for stream reaches in the Thermopolis Anticline Area (figs. 3 and 4). Changes in chemical load, isotopic ratios, and chemical ratios were examined in relation to tributary inflow, surficial geology, and anticlines. In the Thermopolis Anticline Area, the effect of water from three tributaries mixing with water in Owl Creek (fig. 2) was too small to account for the chemical load changes in the area. In the stream reach between SW-10 and SW-14, flow from Pumpkin Draw, Pumpkin Creek, and Mud Creek accounted for about 2 percent of the increased flow and contributed less than 2 percent of the increased chemical load for dissolved solids and sulfate (fig. 4).

No direct relation was apparent between the change in chemical loading and any specific geologic unit in the Thermopolis Anticline Area. Plots of dissolved-solids and sulfate load as functions of changes in surficial geologic units in the drainage basin did not indicate any apparent relation.

A chemical loading increase coincided with the approximate physical location of the Thermopolis Anticline, and the change in water chemistry of Owl Creek had been hypothesized to relate to inflow from the Thermopolis Anticline geothermal system. Water levels were measured to determine any potential interconnection between the water in Owl Creek and ground water in the geothermal system. Water levels were measured in two wells, GW-9 and GW-10, and a spring, GW-11, located along the general ground-water flow path in the geothermal system(Hinckley and others, 1982) (fig. 10). Water levels in the geothermal system were projected to be about 147 feet below the bottom of the Owl Creek channel. The maximum water-level fluctuation over a 9-year period in wells GW-9 and GW-10 was about 10 feet (Kennedy and Green, 1992), much less than the 147 feet. Even with maximum fluctuation, water levels in the geothermal system are well below the level of Owl Creek. In addition to the water-level measurements, water samples were collected from the two wells used for monitoring and one spring that discharges from the geothermal system. Ratios of lithium to chloride in the geothermal water samples were compared to the same ratios for the stream-water samples collected in the Thermopolis Anticline Area. No significant change in the lithium to chloride ratio was measured in stream-water samples (fig. 11) in the Thermopolis Anticline Area, indicating no inflow from the geothermal system to Owl Creek. 

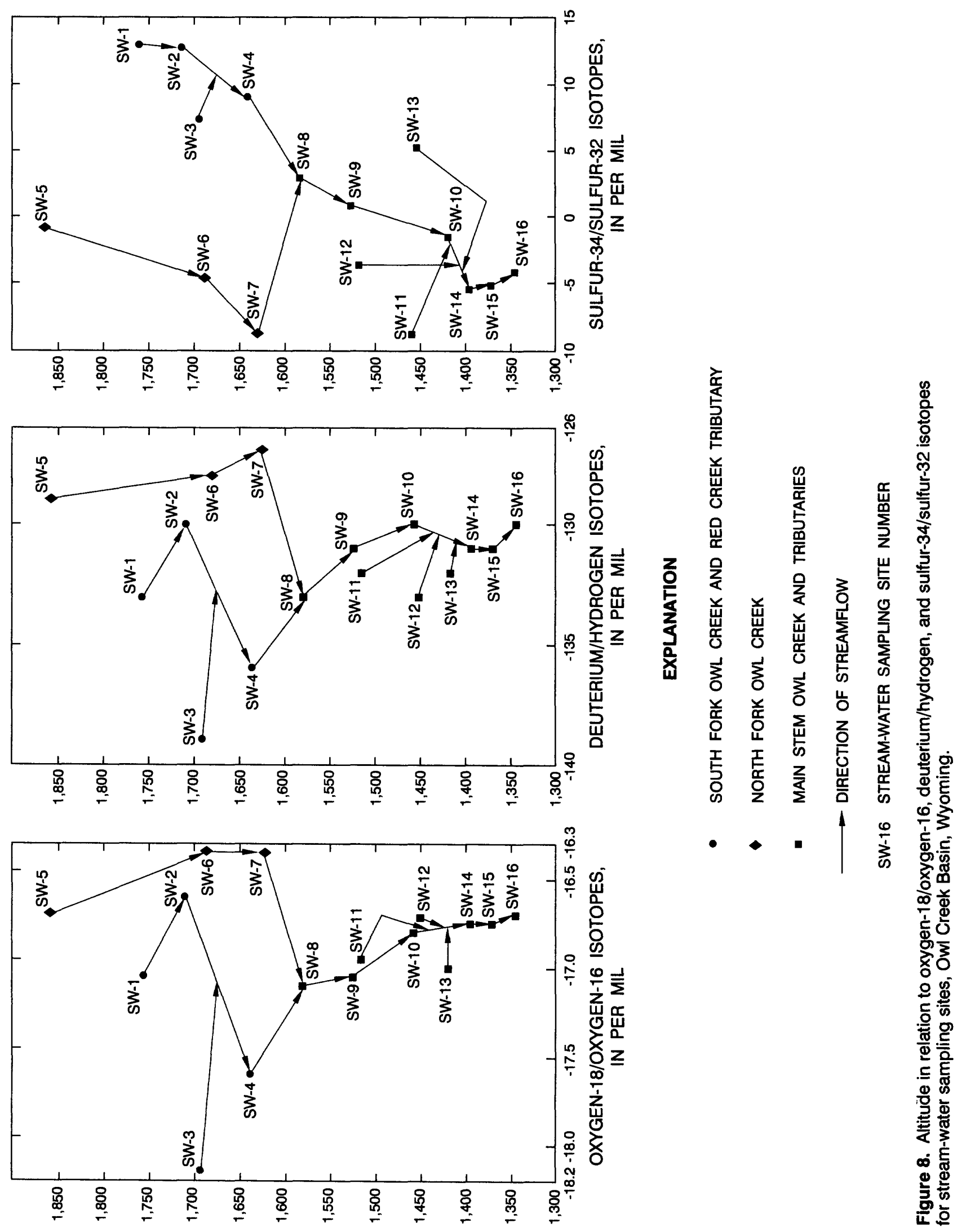

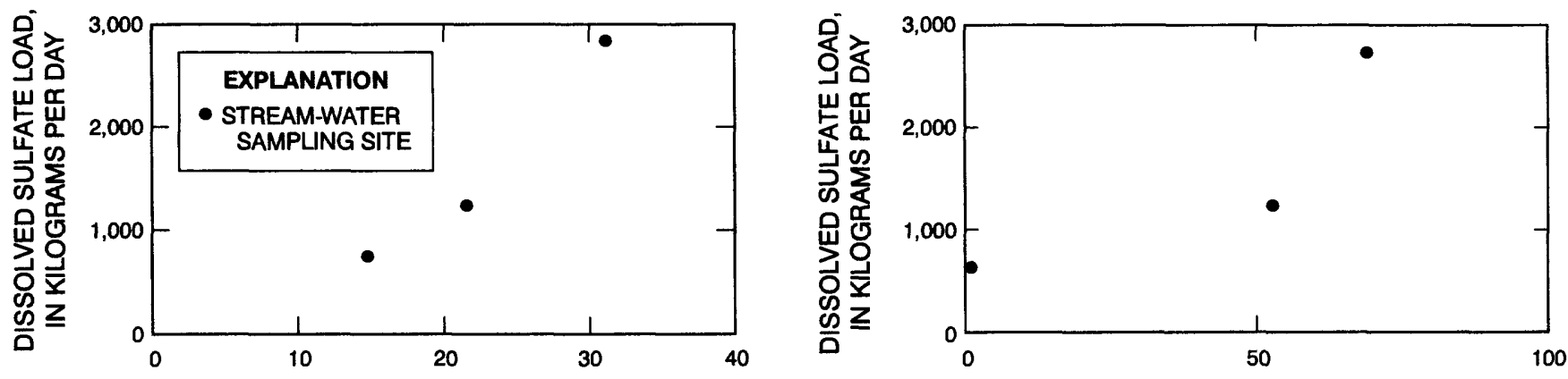

NORTH FORK OWL CREEK
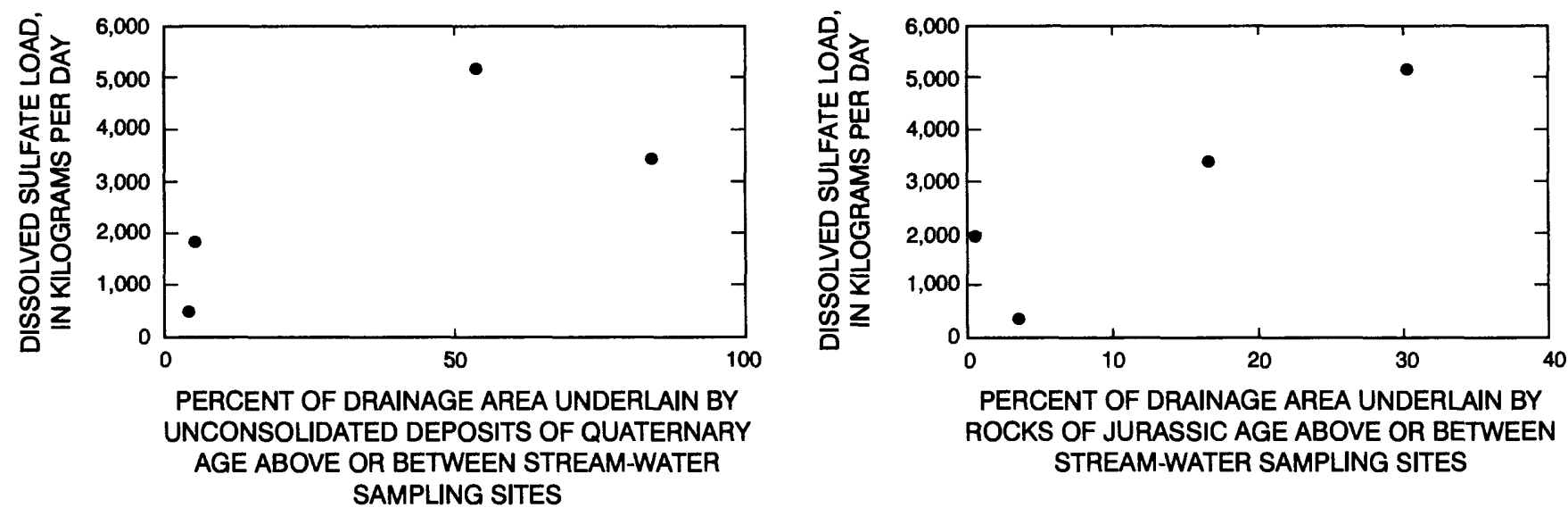

SOUTH FORK OWL CREEK AND RED CREEK

Figure 9. Sulfate loads in relation to unconsolidated quaternary deposits, and to Cretaceous and Jurassic rocks at stream-sampling sites, North Fork and South Fork Owl Creek Basin, Wyoming. 


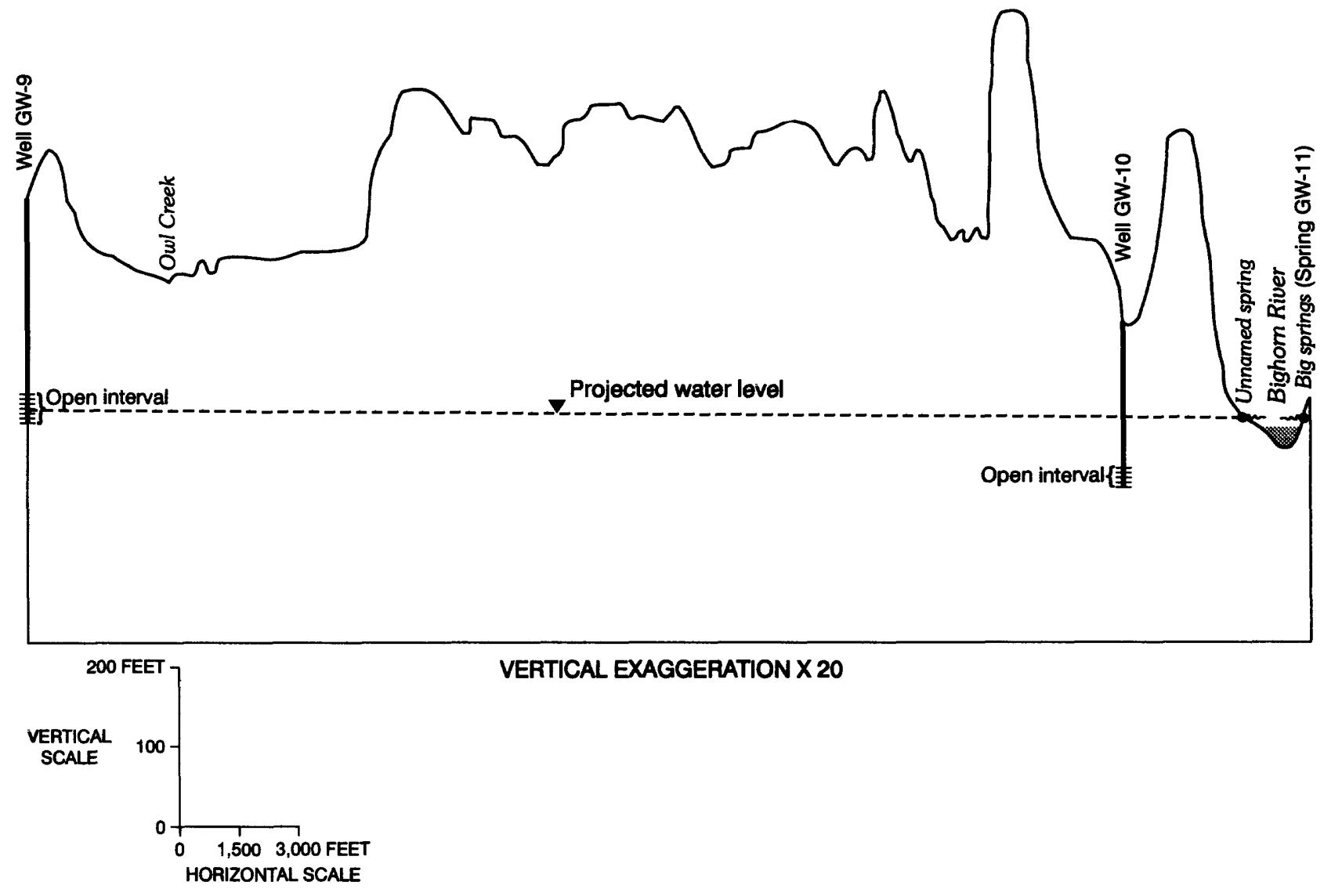

Figure 10. Sketch of land surface and projected water level in the Thermopolis Anticline geothermal system, September 18,1991, Owl Creek Basin, Wyoming. Locations of the two wells and spring are shown in figure 5. 


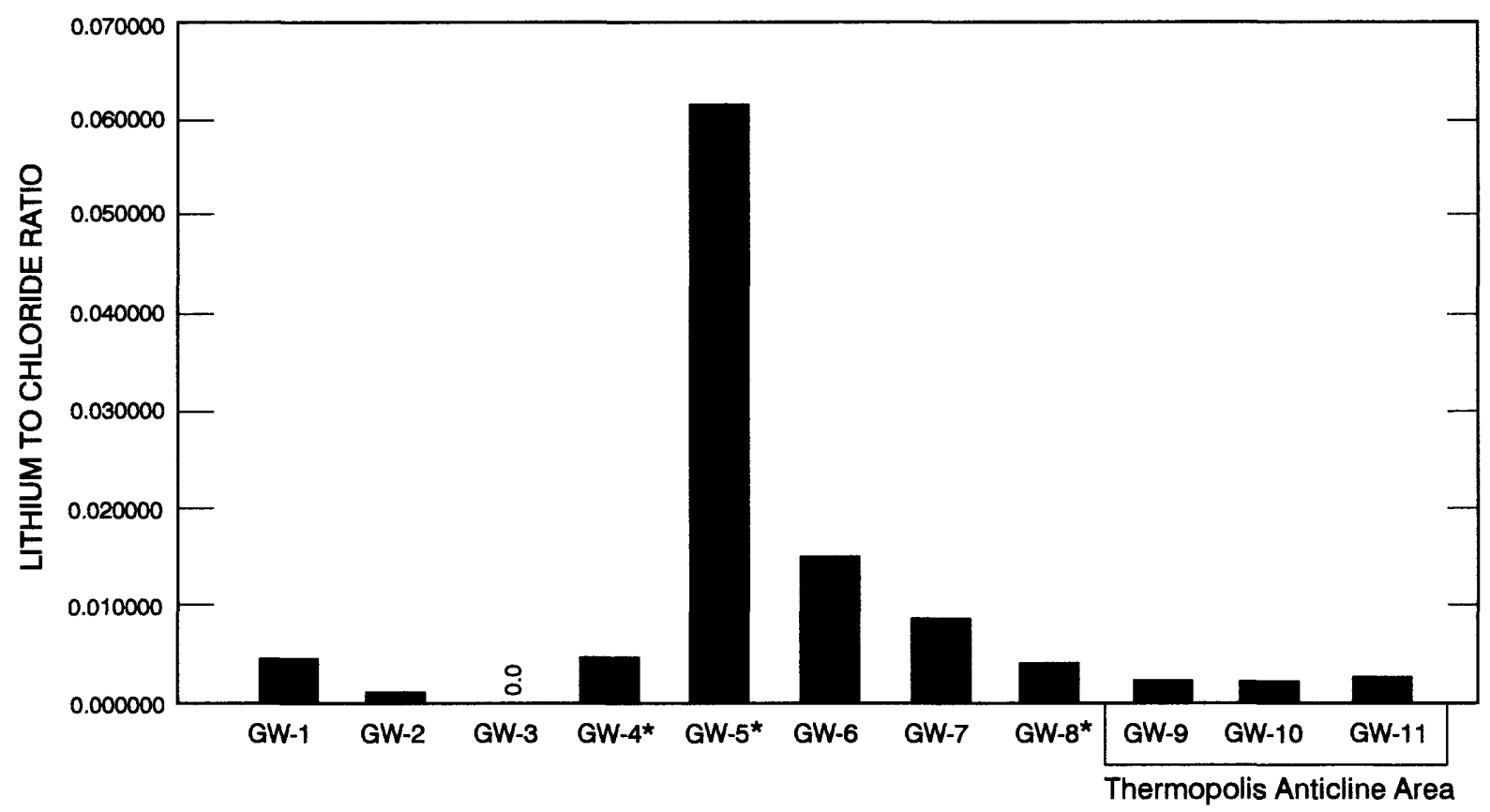

GROUND-WATER SAMPLING SITES

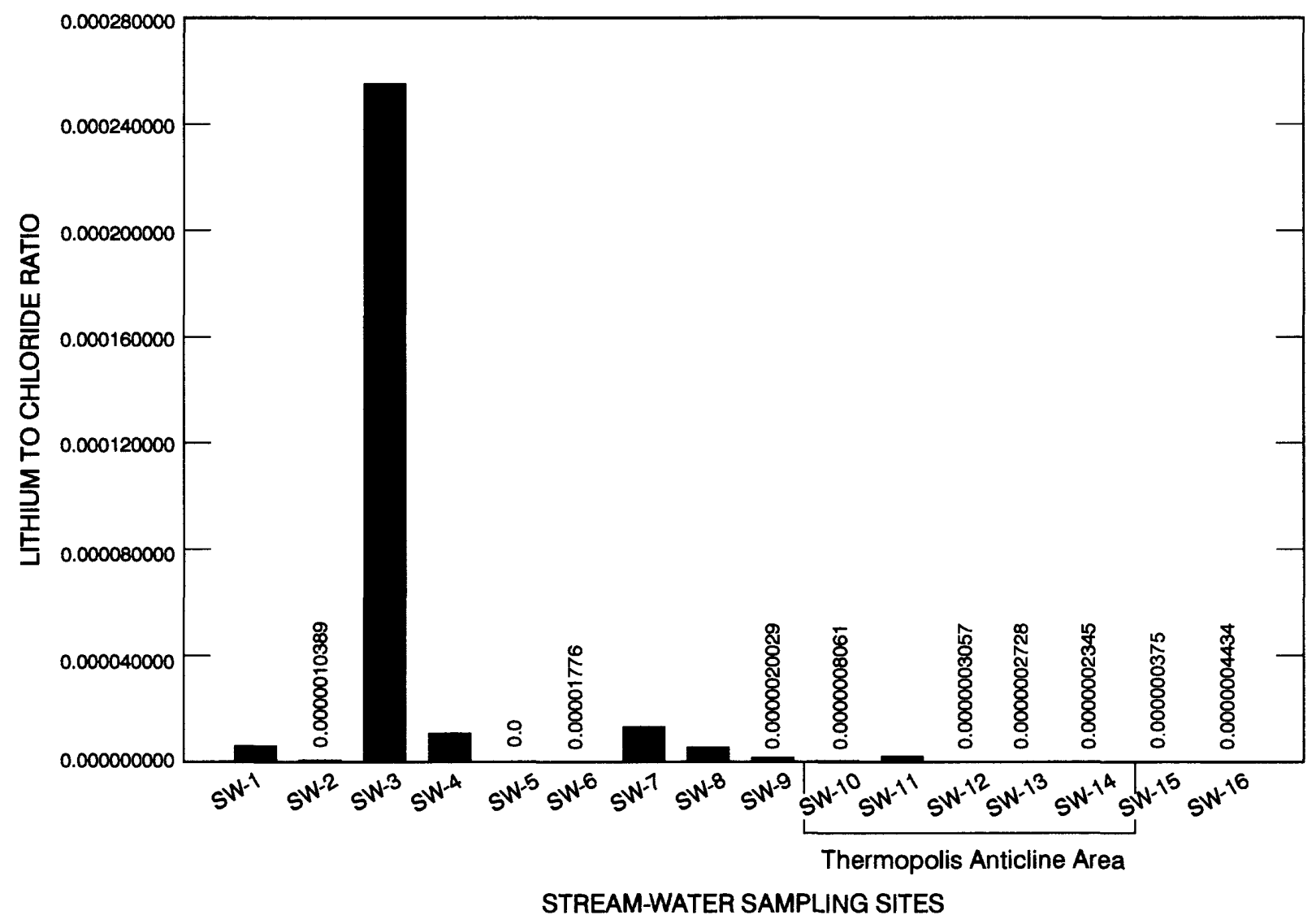

Figure 11. Lithium to chloride ratio of water samples from stream- and ground-water sampling sites, Owl Creek Basin, Wyoming. Ground-water samples are from springs (asterisk) and wells. 
The increase in chemical loading in Owl Creek, as it flowed through the Thermopolis Anticline area, was not related to tributary inflow, surficial geology, or the anticline. Possibly, a complex relation between the unconsolidated deposits and the Thermopolis Anticline resulted in the increased chemical load to Owl Creek. Water discharge from the unconsolidated deposits may be caused by the physical constriction of the Thermopolis Anticline on the ground-water flow system. Ow1 Creek, between the Embar Area and the Thermopolis Anticline Areas, was a losing stream. Streamflow decreased from $16 \mathrm{ft}^{3} / \mathrm{s}$ at SW-8, to $13 \mathrm{ft}^{3} / \mathrm{s}$ at SW-9, to $4.0 \mathrm{ft}^{3} / \mathrm{s}$ at SW-10 (table 2 and fig. 2). Streamflow increased from $4.0 \mathrm{ft}^{3} / \mathrm{s}$ at $S W-10$, to $15 \mathrm{ft}^{3} / \mathrm{s}$ at SW-14 (table 2 and fig. 2). Thus, about an equal amount of flow was gained in the Thermopolis Anticline Area as was lost between the Embar and Thermopolis Anticline Areas. Unconsolidated deposits are up to 5 miles wide between the two areas (Cooley and Head, 1982). In the Thermopolis Anticline Area, however, Owl Creek cuts through the Thermopolis Anticline, and the width of unconsolidated deposits available for the ground-water flow is limited. Perhaps ground water is being forced back into the stream in the Thermopolis Anticline Area. Examination of this more complex hypothesis was beyond the scope of this study.

\section{SUMMARY}

Ground water may contribute substantial inflow to streams during base flow periods and this inflow may affect the water chemistry of streams. The objectives of this study were to identify stream reaches receiving ground-water inflow and to determine the source of increased chemical load in stream water. Stream reaches receiving ground-water inflow were identified using streamflow measurements, radon-222 activity load, and dissolved-solids load. Three potential sources of increased chemical load were analyzed: tributary inflow, variation in surficial geology, and presence of anticlines. A previous study in the Owl Creek Basin, Wyoming, identified two areas where changes in stream-water quality occurred.

An initial field screening of 40 stream-water sampling sites was completed in October 1991 in the Owl Creek Basin. Sixteen of the 40 sites were selected for streamflow measurements, radon-222 activity measurements, and water-quality sampling. Measurements were made and samples were collected during lowflow conditions November 13 - 17, 1991. For compar- ative purposes, water from six wells and five springs also was sampled in the basin.

Eight reaches were identified as receiving ground-water inflow using streamflow measurements, radon-222 activity load, and dissolved-solids load. Streamflow measurements identified three stream reaches receiving ground-water inflow. Analysis of radon-222 activity load identified five reaches receiving ground-water inflow. Dissolved-solids load identified six reaches receiving ground-water inflow. The stream reaches identified by those individual analyses were synthesized to identify two areas of ground-water inflow, the Embar Area and the Thermopolis Anticline Area. These areas were evaluated to determine the sources of increased chemical loads in stream water.

In the Embar Area, two factors, tributary inflow and surficial geology, were related to increased chemical loading. Isotopic ratios of ${ }^{18} \mathrm{O} /{ }^{16} \mathrm{O}, \mathrm{D} / \mathrm{H}$, and ${ }^{34} \mathrm{~S} /{ }^{32} \mathrm{~S}$ indicated tributary inflow affected streamwater chemistry where Red Creek flows into South Fork Owl Creek and at the confluence of North Fork and South Fork Owl Creek. Increased loads of dissolved solids and sulfates were related to an increase in the percentage of unconsolidated deposits of Quaternary age and deposits of Cretaceous and Jurassic age in the drainage area between the stream-water sampling sites on both North Fork and South Fork Owl Creek. The Owl Creek Anticline in the Embar Area did not appear to be associated with increased chemical load in stream water.

In the Thermopolis Anticline Area, changes in water chemistry in Owl Creek did not relate to tributary inflow, to surficial geology, or to ground-water flow from the Thermopolis Anticline geothermal system. Mixing of stream water from tributaries with Owl Creek occurred in the Thermopolis Anticline Area, but the effect of the mixing was too small to account for increases in chemical loading observed in the area. Plots of chemical load did not indicate a direct relation to changes in surficial geology. Inflow of ground water from the geothermal system had been postulated as a source of the increase in chemical load in Owl Creek. Projected water levels in the geothermal system, however, were approximately 147 feet below the stream, and the lithium to chloride ratio did not indicate inflow of water from the geothermal system. The increase in chemical loading might be due to ground water being forced back into the stream from unconsolidated deposits by the physical constriction of the Thermopolis Anticline on the ground-water flow system. However, examination of this more complex hypothesis was beyond the scope of this study. 


\section{REFERENCES}

Cooley, M.E. and Head, W.J., 1982, Hydrogeologic features of the alluvial deposits in the Owl Creek Valley, Bighorn Basin, Wyoming: U.S. Geological Survey Water-Resources Investigations Report 82-4007, 33 p.

Drever, J.I., 1982, The geochemistry of natural waters: Englewood Cliffs, New Jersey, Prentice Hall, 437 p.

Fishman, M.J., and Friedman, L.C., 1989, Methods for determination of inorganic substances in water and fluvial sediments, ( 3 rd ed.): Techniques of WaterResources Investigations of the U.S. Geological Survey, book 5, chap. A1, 626 p.

Fritz, P., 1981, River waters (chapter 8), in Gate, J.R., and Gonfiantini, R. (eds.), Stable isotope hydrology, IAEA: Technical Report Series, no. 210, p. 177-201.

Hall, F.R., 1968, Base-flow recessions--a review: Water Resources Research, v. 4, no. 5, p. 973-983.

Heasler, H.P., 1985, An analysis of the geothermal potential near Western Area Power Administration's facility in Thermopolis, Wyoming: Laramie, University of Wyoming, $42 \mathrm{p}$.

Hem, J.D., 1989, Study and interpretation of the chemical characteristics of natural water: U.S. Geological Survey Water-Supply Paper 2254, 263 p.

Hinckley, B.S., Heasler, H.P., and King, J.K., 1982, The Thermopolis hydrothermal system with an analysis of Hot Springs State Park: The Geological Survey of Wyoming, Preliminary Report, no. 20, 42 p.

Kalkhoff, S.J., 1993, Using a graphical information system to determine the relation between stream quality and geology in the Roberts Creek watershed, Clayton County, Iowa: Water Resources Bulletin, v. 29, no. 6, p. $989-996$.

Kennedy, H.I., and Green, S.L., 1992, Ground-water levels in Wyoming, 1982 through September 1991: U.S. Geological Survey Open-File Report 92-111, 124 p.

Lane, D.W., 1973, The Phosphoria and Goose Egg Formations in Wyoming: The Geological Survey of Wyoming, Preliminary Report, no. 12, 24 p.

Lee, R.W., and Hollyday, E.F., 1987, Radon measurement in streams to determine location and magnitude of ground-water seepage, in Graves, Barbara (ed.), Radon, radium, and other radioactivity in ground water-Proceeding of the NWWA Conference, April 7-9, 1987 : Chelsea, Michigan, Lewis Publishers, 546 p.
1991, Use of radon measurements in Carters Creek, Maury County, Tennessee, to determine location and magnitude of ground-water seepage, in Gundersen, L.C.S., and Wanty, R.B. (eds.), Field studies of radon in rocks, soils, and water: U.S. Geological Survey Bulletin 1971, p. 237-242.

Love, J.D., and Christiansen, A.C., 1985, Geologic map of Wyoming: U.S. Geological Survey, 3 sheets, scale 1:500,000.

Love, J.D., Christiansen, A.C., Brown, T.M., and Earle, J.L. (Compilers), 1979, Preliminary geologic map of the Thermopolis $1^{\circ} \times 2^{\circ}$ quadrangle, central Wyoming: U. S. Geological Survey Open-File Report 79-962, scale $1: 100,000$.

Martner, B.E., 1986, Wyoming climate atlas: Lincoln, Nebraska, University of Nebraska Press, 432 p.

Ogle, K.M., 1992, Surface- and ground-water quality in the Owl Creek basin, north-central Wyoming: U.S. Geological Survey Water-Resources Investigations Report 91-4108, 65 p.

Ogle, K.M., and Lee, R.W., 1994, Activities and summary statistics of radon-222 in stream- and ground-water samples, Owl Creek Basin, north-central Wyoming, September 1991 through March 1992: U.S. Geological Survey Open-File Report 94-93, 15 p.

Rantz, S.E., and others, 1982, Measurement and computation of streamflow, v. 1. Measurement of stage and discharge, v. 2. Computation of discharge: U.S. Geological Survey Water-Supply Paper 2175, 631 p.

Rogers, A.S., 1958, Physical behavior and geologic control of radon in mountain streams: U. S. Geological Survey Bulletin 1052-E, 197 p.

See, R.B., Naftz, D.L., Peterson, D.A., Crock, J.G., Erdman, J.A., and Severson, R.C., 1992, Detailed study of selenium in soil, representative plants, water, bottom sediment, and biota in the Kendrick Reclamation Project Area, Wyoming, 1988-90: U.S. Geological Survey Water-Resources Investigations Report 91-4131, 142 p.

Spencer, S.A., 1986, Groundwater movement in the Paleozoic rocks and impact of petroleum production on water levels in the Southwestern Bighorn Basin, Wyoming: Laramie, University of Wyoming, unpublished Master's thesis, $116 \mathrm{p}$.

Todd, D.K., 1980, Ground water hydrology (2nd edition): New York, John Wiley and Sons, 535 p.

U.S. Environmental Protection Agency, 1980, Prescribed procedures for measurement of radioactivity in drinking water: EPA/UOO/2-87/082, $133 \mathrm{p}$. 
1990, Drinking water regulations under the Safe

Drinking Water Act: Criteria and Standards Division, Office of Drinking Water, U.S. Environmental Protection Agency, Safe Drinking Water Act Fact Sheet, May 1990, 43 p.

Wanty, R.B., and Schoen, Robert, 1991, A review of the chemical processes affecting the mobility of radionuclides in natural waters, with applications, in, Gundersen, L.C.S. and Wanty, R.B. (eds.), Field studies of radon in rocks, soils, and water: U. S. Geological Survey Bulletin 1971, p. 183-192.

Whittaker, E.L., Akridge, J.D., and Giovino, J., 1987, Two test procedures for radon in drinking water interlaboratory collaborative study: EPA/600/2-87/082, $45 \mathrm{p}$. 